\title{
Application of probiotics for acute respiratory tract infections
}

\author{
Oxana Zolnikova, ${ }^{1}$ Inna Komkova, ${ }^{2}$ Nino Potskherashvili, ${ }^{2}$ Alexander Trukhmanov, ${ }^{1}$ Vladimir Ivashkin ${ }^{1}$ \\ ${ }^{1}$ Internal Diseases Propedeutics, I.M. Sechenov First Moscow State Medical University, Moscow; ${ }^{2}$ Vasilenko Clinic of Internal \\ Disease Propedeutics, Gastroenterology, and Hepatology, I.M. Sechenov First Moscow State Medical University, Moscow, \\ Russian Federation
}

\begin{abstract}
We have reviewed the currently published results on a role of the gut microflora in a prevention of acute respiratory infections. The main biological properties of probiotic bacteria are presented in a context of their modulating activity on an inflammatory immune response. Available data on the reduction of a possible risk, duration, and severity of respiratory infection symptoms during a probiotic medication intake were analyzed. Potential antiviral probiotic mechanisms have been reviewed and discussed.
\end{abstract}

\section{Introduction}

It is recognized, acute respiratory infections (ARIs) are dominating in a global structure of a disease distribution and statistics show the ARIs have surpassing other contagions. Among the currently known respiratory infectants, most of them are viruses (over 200 pathogens). Viral ARI pathogens belong to various virus families, so RNA-containing viruses are more significant: Picornaviridae - rhinoviruses, enteroviruses; Orthomyxoviridae - influenza viruses; Paramyxoviridae - parainfluenza viruses, respiratory syncytial viruses, metapneumoviruses; Reoviridae -

Correspondence: Oxana Zolnikova, Internal Diseases Propedeutics, I.M. Sechenov First Moscow State Medical University, Moscow, Russian Federation (MSMU), Trubetskaya Str., Bld. 8/2, Moscow 119991, Russia. Tel.: +79163916056.

E-mail: ks.med@mail.ru

Key words: Acute respiratory infections; lung microbiome; intestinal microbiome; immunomodulation; probiotic.

Contributions: all authors contributed to this paper with the conception, literature review and analysis; OZ, IK and NP wrote the manuscript; AT and VI reviewed and edited the manuscript critically; all authors approved the final version.

Conflict of interest: the authors declare no conflict of interest.

Received for publication: 28 September 2017.

Revision received: 7 December 2017.

Accepted for publication: 29 January 2018.

This work is licensed under a Creative Commons Attribution NonCommercial 4.0 License (CC BY-NC 4.0).

(C) Copyright O. Zolnikova et al., 2018

Licensee PAGEPress, Italy

Italian Journal of Medicine 2018; 12:32-38

doi:10.4081/itjm.2018.931 rotaviruses; Coronaviridae - coronoviruses, DNA-containing viruses; Adenoviridae - adenoviruses; Rarvoviridae - bocaviruses. There are both well-known and new virus strains among those. The strains were identified thanks to a development of molecular biology research methods in recent years. ${ }^{1}$ Viruses have had a very important ability to change their own antigenic structure. So it leads to a forming of highly toxic strains, which are become resistance to the etiotropic medications.

\section{Acute control of pulmonary inflammation}

The respiratory tract epithelium is an entry gate for viruses. The human organism had been improving its own protective mechanisms for centuries. The nonspecific factors are the first level of protection: tenacious mucus, a continuous motion of the columnar epithelium's cilia, non-specific virus replication inhibitors, secretory immunoglobulin A (IgA) have been contained in the respiratory tract secretion. Other protective factors, such as C-type lectins (conglutinin, mannan-binding protein, surfactant proteins $A$ and $D$ ) are forming the anti-infective barrier, the lectins have been bound to virus carbohydrates to cause its aggregation and to provide their better imbibition by phagocytes. ${ }^{1,2}$ To have an infection, a virus must overcome these non-specific respiratory resistance factors. The main target consists in the ciliated columnar epithelial cells for that. Upon infection, the viral RNA/DNA will be identified by Toll-like receptors (TLR-3) and a gene $(R I G-I)$, which launch a release of early inflammatory mediators: interferons (IFN) type I, so the proapoptotic factors have been enhanced in epithelial cells; tumor necrosis factor- $\alpha$ (TNF- $\alpha$ ) and chemokines (CXCL8 and CXCL11) are activating natural killers (NK) and polymorphonucleocytes. As a result, one 
causes a destruction of viral nucleic acid and limits a virus replication. ${ }^{2,3}$ The influence of viral infection on the dendritic cells (DC) leads to a cascade of reactions with an activation of CD4+ and CD8+ cells and subsequent development of specific T- and B-cell-mediated immunity (Figure 1).

\section{Selective role of commensal microbiota in immune responses to influenza virus}

The human microbiome is the key resource to form and to support natural immunity and adaptive capabilities of the organism. The impact of normal flora on immunoregulation outside of digestive system, particularly in lungs, has been established recently and it is a subject for active research now. Signals have been transmitted by synanthropic bacteria and their metabolites are interacting with TLRs, inducing effector's functions have been bound to an expression of the nuclear transcription factor (NFkB), DCs, $\mathrm{T}$ regulatory lymphocytes, chemokines, and cytokines. Bacterial metabolites, particularly short-chain fatty acids (SCFAs) influence the epithelial and immune cells directly, so the immune response is enhancing significantly. It was demonstrated that SCFAs influenced pattern recognition receptors (PRR) by an activating of NFkB, TNF$\alpha$ and it reduced a stimulation of $\mathrm{PRR}^{3-6}$ (Figure 2). Models of experiments on animals confirm the intestinal microbiota has been involved in a supporting of antiviral respiratory immunity. Specifically, as it was demonstrated by Ichiohe et al., long (for 3 weeks) antibiotic intake reduced a resistance to intranasal influenza A virus infection dramatically. This was accompanied by an increase in viral titers and by a decrease in IgA and IgG levels, and CD8+ and CD4+ $T$ cell deactivation versus the animals without antibiotics. Administering of TLR ligands (commensal bacterial peptidoglycans) restored an antibiotic-suppressed antiviral immune response. ${ }^{4}$ This fact confirms the received signals in the lower gastrointestinal tract, once have been transmitted to the mucosae of other biotopes including the respira-

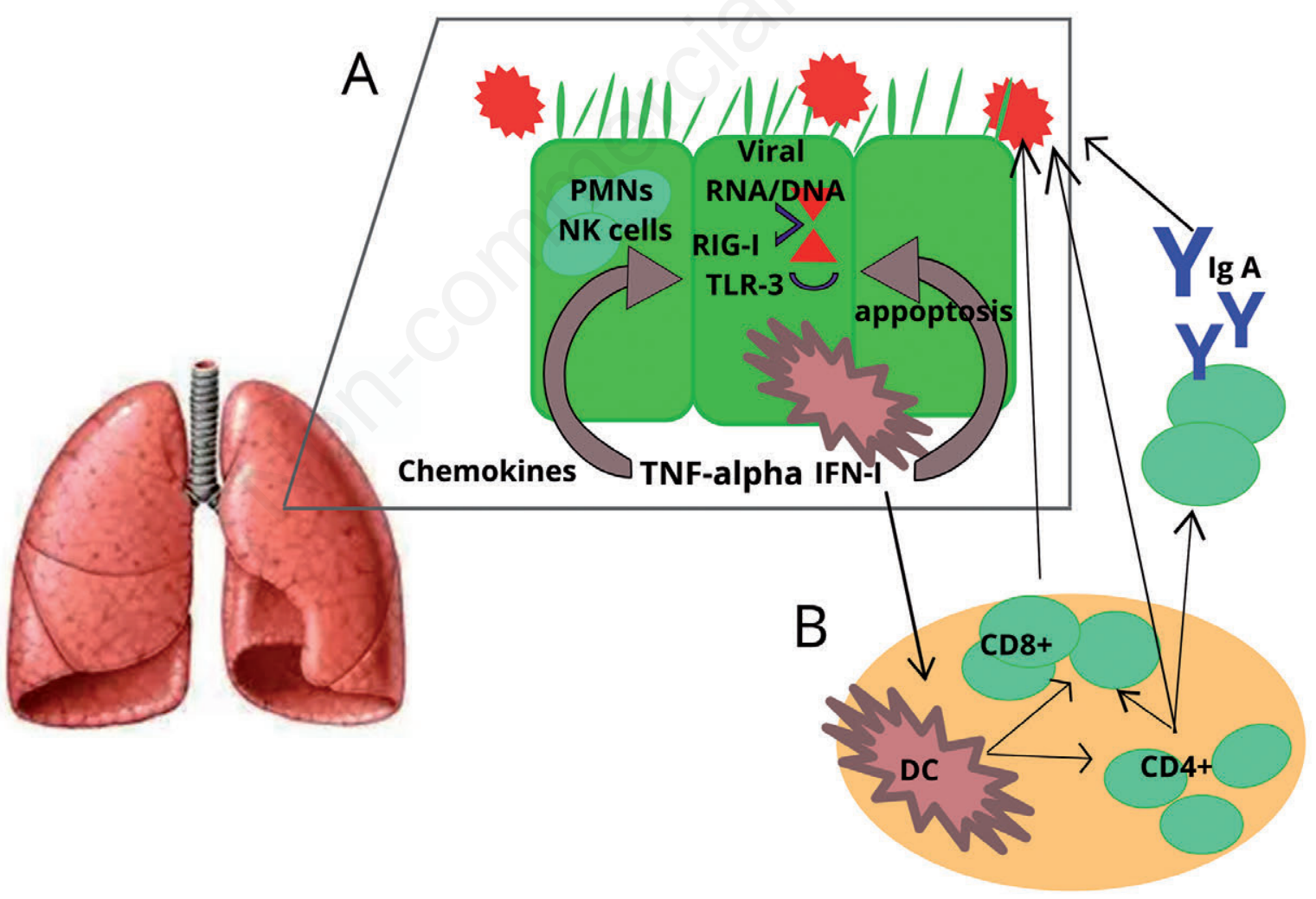

Figure 1. A model of lung immunology response to a virus infection. A) Lung epithelium. The viral RNA/DNA is recognized by TLR-3 and RIG-I receptors, one launches a release of interferons (IFNs), tumor necrosis factor (TNF)- $\alpha$, and chemokines. IFNs type I enhances proapoptotic factors in epithelial cells, whilst TNF- $\alpha$ and chemokines are activating NKs and polymorphonucleocytes (PMNs). The viral RNA/DNA interacts with dendritic cells (DCs). B) Regional lymph nodes. DCs facilitate activation of CD4+ and CD8+ T cells, which migrate back to the infected epithelium with subsequent release of mediators and inflammatory cells including immunoglobulin A (IgA). 
tory tract to enhance a protection against infection. So, it provides a basis to research any capabilities of the probiotic application as for the ARI complex treatment, as for a prevention of the diseases. However, a question has arisen, have all probiotic bacteria got an immunotropic activity? Most of researches are conducted to that and significant intergeneric, interspecific and interstrain differences have been detected in the immunomodulatory activity of symbiotic bacteria now. It had been found, that existing differences were not only in the evidence but also in a matter of the immunotropic effects. ${ }^{7,8}$

\section{Health effects of probiotics in acute respiratory infections}

\section{Animal experiments}

A clinical potential for the probiotic medications was demonstrated by the experiments on animals. It was shown in many articles, an oral or intranasal ad- ministration of the strains of Lactobacillus pentosus, ${ }^{9,10}$ L. casei Shirota, ${ }^{11,12}$ L. plantarum, ${ }^{13,14}$ L. delbrueckii ssp. Bulgaricus OLL1073R1, ${ }^{15}$ L. rhamnosus GG, ${ }^{16,17}$ L. gasseri TMC0356, ${ }^{18}$ Lactococcus lactis ssp. cremoris FC,,$^{19}$ L. brevis $\mathrm{KB}^{20}$ or B. breve YIT4064 $4^{21}$ has helped for a suppression of the infection symptoms for the influenza-virus-infected mice. Simultaneously it induces a decrease of the viral load titers, an amplification of the mucosal immunity (an augmentation of IgA level in the saliva and serum), a more intensive generation of IFNs type I, tumor necrosis factor and an increase of T helpers in the lung parenchyma. Administration of $L$. plantarum NCIMB 8826 and L. reuteri F275 also reduced an inflammation severity and the mortality of the mice that were infected with the pneumovirus. ${ }^{22} \mathrm{Be}-$ sides, L. rhamnosus CRL1505 and L. rhamnosus CRL1506 protected the mice from a respiratory syncytial virus infection. ${ }^{23}$ Simultaneous administration of $L$. rhamnosus and B. lactis contributed to an increase of IFN-y, interleukin (IL)-4, IL-10, and IL-6 in the bronchoalveolar lavage, as well as to the quantity and activity of phagocytic cells and NKs. ${ }^{24,25}$

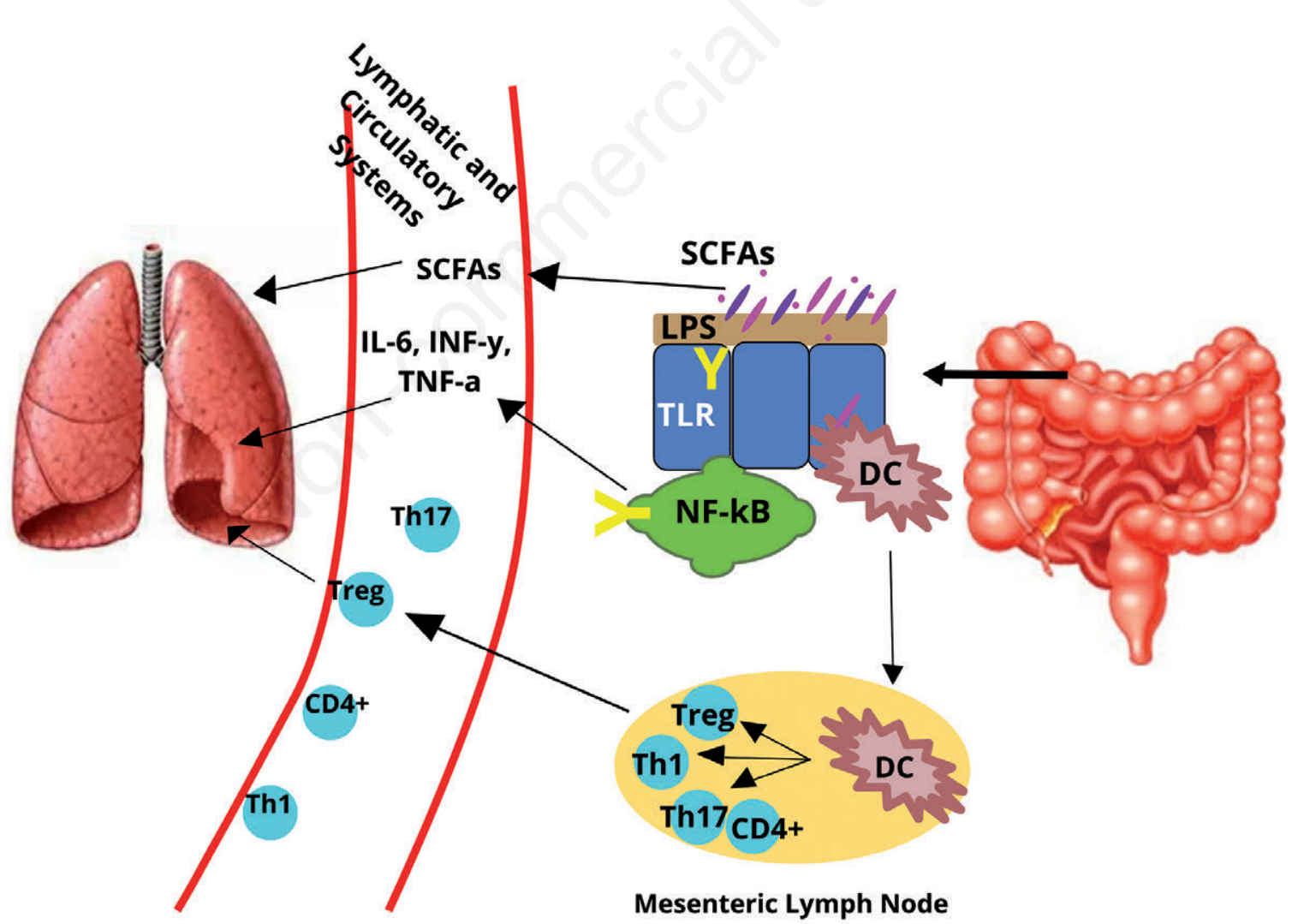

Figure 2. A model of regulatory influence of the gastrointestinal microflora on lung immunology. Intestinal bacteria interact with Toll-like receptors (TLRs) and activate nuclear transcription factor (NFkB) and dendritic cells (DCs) functions as from the bowel lumen directly as after translocation. DCs modulate the activity of $T$ regulatory lymphocytes (Treg) and various regulatory cytokines [interleukin (IL)-10, tumor necrosis factor (TGF)- $\alpha$, interferon (INF)- $\gamma$, IL-6]. Being the bacterial metabolites, short-chain fatty acids (SCFAs) directly influence on epithelial and immune cells, thereby exerting a significant influence on immune response. 


\section{Clinical trials}

The experimental findings generally fit into the clinical impression results. Series of clinical studies for preventive probiotic effects on a viral respiratory infection (across age groups) confirmed the antiviral probiotic efficacy in children (Table 1), in adults (Table 2). ${ }^{26-41}$ Mono-preparations with various content of lactobacillus species/strains and complicated medications with lacto- and bifidobacterium were studied. There are a lot of results related just to an evaluation of the quantity and severity of respiratory infection episodes in the presented studies, whilst only few studies informed about the viral load dynamics. ${ }^{26-41}$ The dosage and the schedule of a probiotic administration used in some trials are presented in the Table 3 .

An analysis of the obtained results is allowed to suggest that effect of probiotic is undoubtedly highly strain-specific and predetermines their clinical efficacy. Interesting information was also obtained on the impact of lactobacilli on postvaccinal immunity.
Davidson et al. have demonstrated that LGG administration for 28 days after vaccination enhanced immune response with a titer augmentation in protective antibodies in comparison with the group to whom influenza vaccine only was administered. ${ }^{42}$ Similar findings were also presented by other researchers. ${ }^{43,44}$ The systematic Cochrane Review was published in 2015. The results of 12 randomized controlled studies were included, they involved 3720 people (across age groups) under probiotic medications for 3 winter months on the average. The probiotics have an advantage over placebos in accordance with the following criteria, as it was found: i) the number of participants after an ARI in the probiotic group, there were fewer [after at least 1 ARI episode: odd ratio (OR) $0.53,95 \%$ confidence interval (CI) 0.37-0.76, $\mathrm{P}<0.001$; subjects after $\geq 3$ episodes: OR $0.53,95 \%$ CI $0.36-0.80$, $\mathrm{P}=0.002]$; ii) it was observed a decrease in the average ARI episode duration [mean difference (MD) -1.89 ; $95 \% \mathrm{CI}-2.03$ to $-1.75, \mathrm{P}<0.001]$ and subjects were

Table 1. Probiotic effect on acute respiratory infections incidence, severity, and symptom duration for children.

\begin{tabular}{|c|c|c|c|}
\hline Author & Population & Probiotic & $\begin{array}{l}\text { Episodes, symptom severity, } \\
\text { and duration }\end{array}$ \\
\hline Hatakka $^{26}$ & 571 children & L. rhamnosus $G G$ & Incident count (below 4 times a year) \\
\hline $\mathrm{Kumpu}^{28}$ & 523 children & Randomized, double blind, placebo-controlled study & $\begin{array}{l}\text { No duration and antibiotic demand } \\
\text { changes }\end{array}$ \\
\hline $\operatorname{Lin}^{36}$ & 1062 children & $\begin{array}{l}\text { L. casei rhamnosus } \\
\text { Double-blind, randomized, controlled study }\end{array}$ & $\begin{array}{l}\text { Less antibiotic demand and bacterial } \\
\text { complications }\end{array}$ \\
\hline Nocerino $^{37}$ & 377 children & $\begin{array}{l}\text { L. paracasei } C B A L 74 \\
\text { Randomized, double-blind, placebo-controlled trial }\end{array}$ & Incident count (below 4 times a year) \\
\hline Hojsak $^{39}$ & 210 children & $\begin{array}{l}\text { B. animalis ssp. Lactis } \\
\text { Randomized, double blind, placebo-controlled study }\end{array}$ & $\begin{array}{l}\text { No duration and incidence changes } \\
\text { Fewer otitis cases }\end{array}$ \\
\hline Caraiova $^{40}$ & 57 children & $\begin{array}{l}\text { L. acidophilus CUL21 and CUL60; B. bifidum CUL20; } \\
\text { B. animalis subsp. lactis } \\
\text { Randomized, double-blind, placebo-controlled study }\end{array}$ & $\begin{array}{l}\text { Duration (under } 4 \text { days)Incident count } \\
\text { (below } 3 \text { times a year)Less school } \\
\text { absence }\end{array}$ \\
\hline Luoto $^{29}$ & $\begin{array}{l}94 \text { premature infants } \\
(32-36 \text { weeks) }\end{array}$ & $\begin{array}{l}\text { L. rhamnosus } G G \\
\text { Randomized, placebo-controlled trial }\end{array}$ & $\begin{array}{l}\text { No duration, severity changes } \\
\text { Incident count (below } 4 \text { times a year) }\end{array}$ \\
\hline Kukkonen $^{30}$ & 925 pregnant & $\begin{array}{l}\text { L. rhamnosus } G G \\
\text { Randomized, double-blind, placebo-controlled trial } \\
\text { Lower antibiotic need }\end{array}$ & $\begin{array}{l}\text { Infant sickness cases (below } 4 \text { times a } \\
\text { year) }\end{array}$ \\
\hline
\end{tabular}

Table 2. Probiotic effect on acute respiratory infections incidence, severity, and symptom duration for adults.

\begin{tabular}{llll}
\hline Author & Population & Probiotic & $\begin{array}{l}\text { Episodes, symptom severity, } \\
\text { and duration }\end{array}$ \\
\hline Turchet $^{33}$ & 360 adults & $\begin{array}{l}\text { L. casei D114001 } \\
\text { Randomized, controlled pilot study }\end{array}$ & $\begin{array}{l}\text { Duration (under } 4 \text { days) } \\
\text { Incident count (below } 3 \text { times a year) }\end{array}$ \\
\hline Guillemard $^{34}$ & 1072 adults & $\begin{array}{l}\text { L. casei D114001 } \\
\text { Randomized, double-blind, placebo-controlled trial }\end{array}$ & $\begin{array}{l}\text { Duration (under 4 days) } \\
\text { Incident count (below } 3 \text { times a year) }\end{array}$ \\
\hline De Verse ${ }^{41}$ & 479 adults & $\begin{array}{l}\text { L. gasseri PA16/8, B. longum SP07/3, B. bifidum MF 20/5 } \\
\text { Randomized, double-blind, controlled trial }\end{array}$ & $\begin{array}{l}\text { Duration (under 3 days) } \\
\text { Incident count (below } 4 \text { times a year) }\end{array}$ \\
\hline
\end{tabular}


significantly less likely to resort to antibiotic treatment during that period, after an intake of probiotics [risk ratio (RR) 0.65 ; $95 \%$ CI $0.45-0.94] .{ }^{45}$

Probiotic prescription to children is a separate matter. As it was proved in the published systematic review and meta-analysis in 2016, the probiotic prescription to children (6269 people from infants to 18 -year-olds) reduced morbidity. The number of patients with 1 ARI episode (RR 0.89, 95\% CI 0.82-0.96, $\mathrm{P}=0.004$ ) was much lower, with a total decrease of sick days (MD $0.16 ; 95 \% \mathrm{CI}-0.29$ to $-0.02, \mathrm{P}=0.03$ ). Children with a probiotic administration were absented in school or needed in a day-patient treatment for fewer days (MD $-0.94,95 \%$ CI -1.72 to $-0.15, \mathrm{P}=0.02){ }^{46}$ Thereby, a point of view of evidential medicine is that a probiotic administration significantly benefits ARI prevention both in the adult and infant population.

With regard to pneumonia, probably, the probiotics place and role in treatment of community-acquired pneumonia will be long discussed. Basically, the probiotic application is being considered from the point of view of a microbiotic correction after antibiotic treatment. Nosocomial infection prevention and treatment with probiotic administration are very interesting for scientists. A meta-analysis carried out on 2972 patients in intensive care units was published in $2016 .{ }^{47}$ In the analysis, a decrease in nosocomial infection incidence (RR 0.80, 95\% CI 0.68-0.95, $\mathrm{P}=0.009$ ) and an increase in the incidence for ventilator-associated pneumonia in patients with artificial lung ventilation (RR $0.74,95 \%$ CI 0.61-0.90, $\mathrm{P}=0.002$ ) were confirmed ${ }^{47}$

\section{Possible mechanism of actions of symbiotic bacteria in respiratory virus infections}

To date, key molecular mechanisms have been disclosed in accordance with the symbiotic bacteria en- hance virus response. Perhaps, the antiviral probiotic effects could be realized by various ways. First of all, there is evolutionary antagonism between bacteria and viruses. It was established that the symbiotic bacterial flora continually produces nucleolytic enzymes (nucleases), which are circulating in the blood and lymph. These enzymes could be responsible for a proteolysis of virion capsids. ${ }^{4,7}$ Besides, peptidoglycans and muramyl peptides, as a part of the bacterial wall, significantly enhance the antiviral bodily protection. Interacting with intracellular NOD-receptors, they have additionally induced a signal cascade of reactions, which results into a synthesis for inflammatory cytokines by immune competent cells and activation of bodily immunoprotection mechanisms. ${ }^{48,49}$ Probiotics can block a virus attachment also by a competition process for certain receptors. Mucosa regeneration is augmented by mucin ability to prevent the virus attachment to epithelial cells and suppress the virus replication. The antiviral effect of probiotics is also related to their ability to produce antimicrobial peptides, dehydrogenases and NOs. Probiotics have also shown an ability to modulate the functions of epithelial cells, dendritic cells, CD4+ CD8+ T lymphocytes, NK cells, and stimulate synthesis of secretory immunoglobulins helping neutralize a virus. ${ }^{50,51}$

\section{Conclusions}

Recent researches on the human microbiome composition and functions have aroused a great interest for a target of a probiotic application and development to prevent ARIs. However, the question about probiotic microorganisms properties, which has to be underlined for a prevention or treatment choice against this particular pathology, remains open. Based on tax-

Table 3. The dosage and the schedule of a probiotic administration.

\begin{tabular}{|c|c|}
\hline Population & Probiotic \\
\hline $\begin{array}{l}571 \text { children forming } \\
\text { Hatakka }^{26}\end{array}$ & $\begin{array}{l}\text { An average volume of milk (with L. rhamnosus } G G \text { ATCC } 53103) \text { was } 260 \mathrm{~mL}\left(1 \% \text { fat and } 5-10 \times 10^{5} \text { colony }\right. \\
\text { units/mL (c.f.u.) of strain LGG) for a daily consumption for over seven months }\end{array}$ \\
\hline $\begin{array}{l}94 \text { premature } 2 \times 10^{9} \text { infants } \\
\text { (birth weight, }>1500 \mathrm{~g} \text { ) } \\
\text { gestational age } 32-36 \text { weeks } \\
\text { Luoto }^{29}\end{array}$ & $\begin{array}{l}\text { L. rhamnosus } G G \text { ATCC } 53103 \text { for the } 1^{\text {st }} \text { and } 60 \text { days of lifeAt a dose of } 1 \times 10^{9} \text { c.f.u/day for } 1 \text { to } 30 \text { days and } \\
\text { c.f.u/day for } 31 \text { to } 60 \text { daysThe products with approximately } 10 \mathrm{~mL} \text { of breast milk were mixed right before an } \\
\text { administration to the infants }\end{array}$ \\
\hline $\begin{array}{l}925 \text { pregnant } \\
\text { 2-year follow-up } \\
\text { Kukkonen }^{30}\end{array}$ & $\begin{array}{l}\text { During the } 2 \text { to } 4 \text { weeks before delivery, mothers twice daily took } 1 \text { capsule containing L. rhamnosus GG (ATCC } \\
53103), 5 \times 10^{9} \text { c.f.u.; L rhamnosus LC705(DSM 7061), } 5 \times 10^{9} \text { c.f.u.; Bifidobacterium breve Bb99 (DSM 13692), } \\
2 \times 10^{8} \text { c.f.u.; Propionibacterium freudenreichii ssp. shermanii JS (DSM 7076), } 2 \times 10^{9} \text { c.f.u. } \\
\text { Their newborn infants received } 1 \text { opened capsule containing the same probiotics mixed with } 20 \text { drops of sugar } \\
\text { syrup containing } 0.8 \mathrm{~g} \text { of galacto-oligosaccharides once daily for } 6 \text { months after birth }\end{array}$ \\
\hline $\begin{array}{l}494 \text { children }^{3} \\
\text { Agustina }^{32}\end{array}$ & $\begin{array}{l}\text { L. casei D114001; L. reuteri DSM } 17938180 \mathrm{~mL} \text { of milk twice daily } 6 \text { month } 100 \mathrm{~mL} \text { of milk with } 5 \times 10^{8} \text { c.f.u. } \\
\text { per day of } L \text {. casei } C R L 431 \text {, or one with } 5 \times 10^{8} \text { c.f.u. per day of Lactobacillus reuteri DSM } 17938\end{array}$ \\
\hline $\begin{array}{l}479 \text { adults } \\
\text { De Verse }\end{array}$ & L. gasseri PA16/8; B. longum SP07/3; B. bifidum $M F 20 / 55 \times 10^{7}$ c.f.u./tablet during 3 months, at least \\
\hline
\end{tabular}


onomic, most of the commonly used probiotic bacteria are the Lactobacillus and Bifidobacterium species. However, their probiotic effects have had a strain specificity, which is obviously affecting their biological activity.

A capability of the probiotic administration for ARI prevention and treatment could be more effective, as it was demonstrated by the presented meta-analysis results.

\section{References}

1. Allander T, Tammi MT, Eriksson M. Cloning of a human parvovirus by molecular screening of respiratory tract samples. Proc Natl Acad Sci U S A 2005;102:12891-6.

2. Rossi GA, Colin AA. Infantile respiratory syncytial virus and human rhinovirus infections: respective role in inception and persistence of wheezing. Eur Respir J 2015;45:774-89.

3. Openshaw PJ, Tregoning JS. Immune responses and disease enhancement during respiratory syncytial virus infection. Clin Microbiol Rev 2005;18:541-55.

4. Ichiohe T, Pang IK, Kumamoto Y. Microbiota regulates immune defense against respiratory tract influenza A virus infection. Proc Natl Acad Sci U S A 2011;108:5354-9.

5. Evsyutina Y, Komkova I, Zolnikova O, et al. Lung microbiome in healthy and diseased individuals. World J Respirol 2017;7:39-47.

6. Samuelson DR, Welsh DA, Shellito JE. Regulation of lung immunity and host defense by the intestinal microbiota. Front Microbiol 2015;6:1085.

7. Salva S, Alvarez S. The role of microbiota and immunobiotics in granulopoiesis of immunocompromised hosts. Front Immunol 2017;8:507.

8. Lopez P, Gonzalez-Rodrıguez I, Gueimonde M, et al. Immune response to Bifidobacterium bifidum strains support Treg/Th17 plasticity. PLoS One 2011;6:e24776.

9. Izumo T, Maekawa T, Ida M, et al. Effect of intranasal administration of Lactobacillus pentosus S-PT84 on influenza virus infection in mice. Int Immunopharmacol 2010;10:1101-6.

10. Kobayashi N, Saito T, Uematsu T, et al. Oral administration of heat-killed Lactobacillus pentosus Strain b240 augments protection against influenza virus infection in mice. Int Immunopharmacol 2011;11:199-203.

11. Hori T, Kiyoshima J, Shida K, Yasui H. Effect of intranasal administration of Lactobacillus casei Shirota on influenza virus infection of upper respiratory tract in mice. Clin Diagn Lab Immunol 2001;8:593-7.

12. Yasui H, Kiyoshima J, Hori T. Reduction of influenza virus titer and protection against influenza virus infection in infant mice fed Lactobacillus casei Shirota. Clin Diagn Lab Immunol 2004;11:675-9.

13. Pang IK, Iwasaki A. Control of antiviral immunity by pattern recognition and the microbiome. Immunol Rev 2012;245:209-26.

14. Villena J, Suzuki R, Fujie H, Chiba E. Immunobiotic Lactobacillus jensenii modulates the Toll-like receptor 4-induced inflammatory response via negative regulation in porcine antigen-presenting cells. Clin Vaccine Immunol 2012;19:1038-53.
15. Nagai T, Makino S, Ikegami S, et al. Effects of oral administration of yogurt fermented with Lactobacillus delbrueckii ssp. bulgaricus OLL1073R-1 and its exopolysaccharides against influenza virus infection in mice. Int Immunopharmacol 2011;11:2246-50.

16. Kawase M, He F, Kubota A, et al. Oral administration of Lactobacilli from human intestinal tract protects mice against influenza virus infection. Lett Appl Microbiol 2010;51:6-10.

17. Harata G, He F, Hiruta N, et al. Intranasal administration of Lactobacillus rhamnosus GG protects mice from H1N1 influenza virus infection by regulating respiratory immune responses. Lett Appl Microbiol 2010;50:597-602.

18. Kawase M, He F, Kubota A, et al. Heat-killed Lactobacillus gasseri TMC0356 protects mice against influenza virus infection by stimulating gut and respiratory immune responses. FEMS Immunol Med Microbiol 2012;64:280-8.

19. Maruo T, Gotoh Y, Nishimura H, et al. Oral administration of milk fermented with Lactococcus lactis subsp. cremoris FC protects mice against influenza virus infection. Lett Appl Microbiol 2012;55:135-40.

20. Goto H, Sagitani A, Ashida N, et al. Anti-influenza virus effects of both live and non-live Lactobacillus acidophilus L-92 accompanied by the activation of innate immunity. Br J Nutr 2013;110:1810-18.

21. Yasui H, Kiyoshima J, Hori T, Shida K. Protection against influenza virus infection of mice fed Bifidobacterium breve YIT4064. Clin Diagn Lab Immunol 1999;6:186-92.

22. Gabryszewski SJ, Bachar O, Dyer KD, et al. Lactobacillus-mediated priming of the respiratory mucosa protects against lethal pneumovirus infection. J Immunol 2011; 186:1151-61.

23. Tomosada Y, Chiba E, Zelaya H, et al. Nasally administered Lactobacillus rhamnosus strains differentially modulate respiratory antiviral immune responses and induce protection against respiratory syncytial virus infection. BMC Immunol 2013; 14:40.

24. Gill HS, Rutherfurd KJ, Cross ML, Gopal PK. Enhancement of immunity in the elderly by dietary supplementation with the probiotic Bifidobacterium lactis HN019. Am J Clin Nutr 2001;74:833-9.

25. Di Cerbo A, Palmieri B, Aponte M, et al. Mechanisms and therapeutic effectiveness of Lactobacilli. J Clin Pathol 2016;69:187-203.

26. Hatakka K, Savilahti E, Ponka A. Effect of long term consumption of probiotic milk on infections in children attending day care centres: double blind, randomised trial. BMJ 2001;322:1327.

27. Hojsak I, Snovak N, Abdovic S, et al. Lactobacillus GG in the prevention of gastrointestinal and respiratory tract infections in children who attend day care centers: a randomized, double-blind, placebo-controlled trial. Clin Nutr 2010;29:312-6.

28. Kumpu M, Kekkonen RA, Kautiainen H, et al. Milk containing probiotic Lactobacillus rhamnosus GG and Respiratory illness in children: a randomized, doubleblind, placebo-controlled trial. Eur J Clin Nutr 2012; 66:1020-3.

29. Luoto R, Ruuskanen O, Waris M, et al. Prebiotic and probiotic supplementation prevents rhinovirus infections in preterm infants: a randomized, placebo-controlled trial. J Allergy Clin Immunol 2014;133:405-13. 
30. Kukkonen K, Savilahti E, Haahtela T. Long-term safety and impact on infection rates of postnatal probiotic and prebiotic (synbiotic) treatment: randomized, double-blind, placebo-controlled trial. Pediatrics 2008;122:8-12.

31. Rautava S, Salminen S, Isolauri E. Specific probiotics in reducing the risk of acute infections in infancy - a randomised, double-blind, placebo-controlled study. Br J Nutr 2009;101:1722-6.

32. Agustina R, Kok FJ, van de Rest O. Randomized trial of probiotics and calcium on diarrhea and respiratory tract infections in Indonesian children. Pediatrics 2012; 129:e1155-64.

33. Turchet P, Laurenzano M, Auboiron S, Antoine JM. Effect of fermented milk containing the probiotic Lactobacillus casei DN-114001 on winter infections in free-living elderly subjects: a randomised, controlled pilot study. J Nutr Aging 2003;7:75-7.

34. Guillemard E, Tondu F, Lacoin F, Schrezenmeir J. Consumption of a fermented dairy product containing the probiotic Lactobacillus casei DN-114001 reduces the duration of respiratory infections in the elderly in a randomised controlled trial. Br J N 2010;103:58-68.

35. Cobo Sanz JM, Mateos JA, Munoz Conejo A. Effect of Lactobacillus casei on the incidence of infectious conditions in children. Nutr Hosp 2006;21:547-51.

36. Lin JS, Chiu YH, Lin NT. Different effects of probiotic species/strains on infections in preschool children: a double-blind, randomized, controlled study. Vaccine 2009;27:1073-9.

37. Nocerino R, Paparo L, Terrin G. Cow's milk and rice fermented with Lactobacillus paracasei CBA L74 prevent infectious diseases in children: a randomized controlled trial. Clin Nutr 2017; V.36:118-25.

38. Maldonado J, Canabate F, Sempere L. Human milk probiotic Lactobacillus fermentum CECT57I6 reduces the incidence of gastrointestinal and upper respiratory tract infections in infants. J Pediatr Gastroenterol Nutr 2012; 54:55-61.

39. Hojsak I, Mocic Pavic A, Kos T, et al. Bifidobacterium animalis subsp. lactis in prevention of common infections in healthy children attending day care centers - randomized, double blind, placebo-controlled study. Clin Nutr 2015;35:587-91.

40. Garaiova I, Muchova J, Nagyova Z. Probiotics and vitamin $\mathrm{C}$ for the prevention of respiratory tract infections in children attending preschool: a randomised controlled pilot study. Eur J Clin Nutr 2015;69:373-9.

41. de Vrese M, Winkler P, Rautenberg P, et al. Effect of Lactobacillus gasseri PA 16/8, Bifidobacterium longum SP 07/3, B. bifidum MF 20/5 on common cold episodes: a double blind, randomized, controlled trial. Clin Nutr 2005;24:481-91.

42. Davidson LE, Fiorino AM, Snydman DR, Hibberd PL. Lactobacillus GG as an immune adjuvant for live-attenuated influenza vaccine in healthy adults: a randomized double-blind placebo-controlled trial. Eur J Clin Nutr 2011;65:501-7.

43. Akatsu H, Arakawa H, Yamamoto T, et al. Lactobacilli in jelly enhances the effect of influenza vaccination. $\mathrm{J}$ Am Geriatr Soc 2013;61:1828-30.

44. Rizzardini G, Eskesen D, Calder PC, et al. Evaluation of the immune effects of two probiotic strains Bifidobacterium animalis, BB lactis, BB-12 and Lactobacillus paracasei ssp. paracasei, L. casei 431 in an influenza vaccination model: a randomized double-blind placebo controlled trial. Br J Nutr 2012;107:876-84.

45. Hao Q, Dong BR, Wu T. Probiotics for preventing acute upper respiratory tract infections. Cochrane Database Syst Rev 2015;2:CD006895.

46. Wang YX, Ge T, Xiao Y, et al. Probiotics for prevention and treatment of respiratory tract infections in children. A systematic review and meta-analysis of randomized controlled trials. Medicine (Baltimore) 2016;95:e4509.

47. Manzanares W, Lemieux M, Langlois PL, Wischmeyer PL. Probiotic and synbiotic therapy in critical illness: a systematic review and meta-analysis manzanares. Crit Care 2016;20:262.

48. Fitzgerald KA. NLR-containing inflammasomes: central mediators of host defense and inflammation. Eur J Immunol 2010;40:595-8.

49. Coulombe F, Fiola S, Akira S, et al. Muramyl dipeptide induces NOD2-dependent Ly6C(high) monocyte recruitment to the lungs and protects against influenza virus infection. PLoS One 2012;7:e36734.

50. Lehtoranta L, Pitkäranta A, Korpela R. probiotics in respiratory virus infections. Eur J Clin Microbiol Infect Dis 2014;33:1289-302.

51. Kim TH, Lee HK. Differential roles of lung dendritic cell subsets against respiratory virus infection. Immune Netw 2014;14:128-37. 